\title{
REPORTS FROM THE NSIS COUNCIL NOVA SCOTIAN INSTITUTE OF SCIENCE
}

\section{PRESIDENT'S REPORT: 2011 TO 2012}

The Nova Scotian Institute of Science (NSIS) celebrated its $150^{\text {th }}$ anniversary in 2012. The Institute exists to provide a forum for scientists and those interested in science to learn about and discuss scientific matters. It promotes this aim through an annual public lecture and discussion series, the publication of a journal (The Proceedings of the Nova Scotian Institute of Science), and maintenance of a website (http://www.chebucto.ns.ca/Science/NSIS/). Through its public outreach, it draws attention to issues of societal concern that intersect the natural and social sciences, such as education, environmental and natural resource policies, and ethics. We seek to promote research and education in science by running a Mentorship Program, conducting an annual Scientific Writing Competition for university students, and supporting Regional Science Fairs. We highlight the contributions made to science and technology by Nova Scotians through our virtual Hall of Fame (http://tinyurl.com/nsis-fame), and provide information of historical interest on our website. The NSIS maintains a library in collaboration with Dalhousie University, which provides digital copies of previous volumes of the Proceedings.

This year's lecture programme was organized by Ron MacKay, Michelle Paon, John Rutherford, and Angelica Silva. Most of the talks were presented at the lecture theatre in the Nova Scotia Museum of Natural History. We are grateful to the Museum, and to the Museum's manager of collections and its representative on Council, Mr. David Christianson, for providing us with meeting space, the use of the theatre, and continued encouragement and support. Members of Council particularly appreciated the demonstration of the "Our Amazing World" installation by Mr. Calum Ewing. The NSIS also co-sponsored the eighth annual Sable Island Update which was held at Saint Mary's University and was attended by approximately 200 people. The 2011-2012 lecture programme was as follows:

Monday, 3 October, 2011 7:30

NS Museum of Natural History

Dr. John Calder: Nova Scotia Department of Natural Resources Coal Age Galapagos 
Monday, 7 November, 2011 7:30

NS Museum of Natural History

Dr. Heike Lotze: Department of Biology, Dalhousie University Food, Furs and Feathers: History of Human-induced Changes in Coastal Ecosystems

\section{Tuesday, 29 November, $2011 \quad 7: 30$}

NS Museum of Natural History

Mr. Cameron Ells: Chair, Shubenacadie Canal Commission

There and Back Again: Along the Shubenacadie Canal in 1861

(Note: Due to popular demand, Mr. Ells kindly repeated his lecture on Monday, February 20, 2012, in the Windsor Lecture Theatre of the Art Gallery of Nova Scotia)

Monday, 5 December, 2011 7:30

NS Museum of Natural History

Dr. Martin Willison: School for Resource and Environmental Studies, Dalhousie University

From Picnic Parks to Systematic Protection of Biodiversity:

A Review of the Development of Protected Areas in Nova Scotia

Monday, January 9, $2012 \quad$ 7:30

NS Museum of Natural History

Dr. Charlie Embree: Atlantic Food and Horticulture Research

Centre, Kentville, Nova Scotia

100 Years of Research in the Orchard

Monday, 6 February, 2012 7:30

NS Museum of Natural History

Dr. Grant Wach: Department of Earth Sciences, Dalhousie University

Burning Rocks: The History of the Petroleum Industry in Canada and the Maritimes

\section{Monday, 2 April, 2012 7:30}

Windsor Lecture Theatre, Art Gallery of Nova Scotia

Dr. Jacob Hanley: Department of Geology, Saint Mary's University A Noble Legacy: The History, Geology, and Future of Gold Mining and Exploration in Nova Scotia 


\section{Monday, 7 May, 2012 7:30}

Alumni Hall, University of King's College

\section{Dr. Bernard Lightman: Director of the Institute for Science and Technology Studies, York University, Toronto, Ontario \\ Communicating Knowledge to New Audiences: Victorian Popular- izers of Science}

(Note: Lecture co-sponsored by the History of Science and Technology Programme at the University of King's College)

The public lectures for the Anniversary Year were presented from a historical perspective, but also included the results of current research in the fields represented. The possibility of collaboration with other institutions in sponsoring speakers was, and continues to be, explored. In particular, potential co-operation with the Royal Nova Scotia Historical Society in sponsoring speakers on topics of mutual interest is being pursued. During the year, the NSIS, the Bedford Institute of Oceanography, and the RNSHS mutually advertised each other's lecture series. To further raise public awareness of our lectures this year, the NSIS talks were publicized using colour brochures and posters that were distributed both on-line and in hard copy. Attendance at lectures was gratifying; the audience typically consisted of between 70 to 80 people. These attendance numbers appear to justify a continuation of the use of high visibility promotional material in the coming year.

Through the efforts of editors Peter Wells and David Richardson and their editorial review board, two issues of the Proceedings were published in 2011. The first (Volume 46, part 1) was a special issue entitled The Birds of Brier Island, by Eric L. Mills and Lance Laviolette. This publication is profusely illustrated with colour photographs, and has been enthusiastically received by the public. Both volumes have benefitted by upgraded production values which include a redesigned cover format, the use of colour, and a more reader-friendly type font. The financial support of the Provincial Department of Communities, Culture and Heritage for our publishing programme is gratefully acknowledged. On January $19^{\text {th }}$, a launch celebrating the digitization of the Proceedings was held at the Killam Library. Thanks to the efforts of Michelle Paon and Sharon Longard, researchers now have on-line access all copies of the Proceedings from its beginnings in 1863 until 1984. The future of the Proceedings was discussed at a 
special extended meeting of Council held on March 5, 2012. Geoff Brown, of the Killam Library, was invited to address Council on the subject of on-line publishing. Mr. Brown presented a very helpful description of the Library's Journal Hosting Service, a web-based publishing application. Following the presentation, Council considered the frequency of publication of the Proceedings, the print and electronic options for publication, and the budget required to produce the journal. It was agreed to publish two issues per year, to establish a budget which would include an increase in the dues to $\$ 30.00$, and to further explore the Dalhousie electronic publication option.

Through the generosity of Dr. Charles Reynes, currently living in California, and with the support and cooperation of the Killam Library, the Institute received a donation of a bound set of volumes I through IV of the Proceedings, a number of paperback journals dating through the 1930s, a number of Canadian maps ca. 1890, and an antique seal of the NSIS logo.

Our Science Writing Competition was once again organized and overseen by Bob Cook. Three students, one each in the undergraduate, graduate and honourable mention category, were awarded certificates at the April meeting of the NSIS. Congratulations are extended to:

In the undergraduate category - William Roberts (Acadia University) for a paper entitled, "An overview of the biology, ecology, conservation and fishing history of the seahorse, Hippocampus sp."

In the graduate category - Suzette Soomai (Dalhousie University) for a paper entitled, "The use and influence of scientific information in environmental policy making: Lessons from Nova Scotia"

Honourable mention - Robert Paul (Dalhousie University) for a paper entitled, "The elusive causal association between gastroesophageal reflux disease (GERD) or colon inflammation and atrial fibrillation (AFIB) and atrial flutter: A review of the literature and new case study"

The NSIS continued to provide financial support to the ten Regional Science Fairs in the form of a donation, for this year alone, of $\$ 150.00$ in prize money, the amount reflecting the Institute's anniversary year. Various members of the NSIS Council were involved in judging projects and presenting awards.

Work was begun this year on updating the NSIS website; Susan Soomai kindly agreed to take on this responsibility. Regis Dudley was welcomed to Council as Publicity Officer. 
The Anniversary Committee, ably and energetically chaired by Michelle Paon, was busy throughout the year planning events to celebrate the Institute's $150^{\text {th }}$ year. At one of those events, the Anniversary Banquet held on Tuesday, May $8^{\text {th }}$ at the Lord Nelson Hotel in Halifax, two distinguished Nova Scotian scientists were inducted into the Hall of Fame: Dr. Kenneth Mann, an eminent, internationally recognized marine ecologist, and Dr. Willard Boyle, recipient of the 2009 Nobel Prize in physics for his contribution to the development of the charge-coupled device. Please see the report of the Committee for further details relating to anniversary events.

In closing, I would like to thank all the members of Council for their ideas, their hard work, and their support. In particular, it is a pleasure to acknowledge Sharon Longard's long and dedicated service to the Institute; Sharon will be retiring after 17 years as the librarian representative on Council. She will be greatly missed. As well, on behalf of Council, I would like to thank Elaine McCulloch (who will continue as a member of Council) for her diligence and expertise as treasurer, and Bob Cook for his enthusiasm in promoting and overseeing the writing programme as its coordinator.

Respectfully submitted, John Rutherford

May 8, 2012 
The following motion was passed in the Nova Scotia Legislature in honour of the $150^{\text {th }}$ Anniversary of the NSIS

RESOLUTION DATE: May 8, 2012

NOTICE OF MOTION

MOVED BY: David A. Wilson

Minister of Communities, Culture and Heritage

MLA, Sackville-Cobequid

I hereby give notice that on a future day I shall move the adoption of the following resolution:

WHEREAS the Nova Scotia Institute of Science celebrates its 150th anniversary in 2012 and has played an important role in supporting and promoting scientific activity in a wide variety of fields such as geology, botany, oceanography, zoology and meteorology; and

WHEREAS the Nova Scotia Institute of Science is one of the oldest such societies in Canada, created by an act of the provincial legislature in 1890, and provides a forum for debate, discussion and a better understanding of the province's connection to science and research ; and

WHEREAS science has played a significant role in the development of our province and remains vital to our future economic, social and environmental progress and is one of the keys to creating an innovative and successful Nova Scotia.

WHEREAS that all members of this House congratulate the Nova Scotia Institute of Science on this important milestone and wish them continued success in their efforts to promote the value of scientific achievement.

Mr.Speaker I request waiver of notice and passage without debate. 


\section{EDITOR'S REPORT}

\section{NSIS ANNUAL GENERAL MEETING \\ May 8th, 2012}

\section{Status of the Proceedings of the NSIS}

Volume 46 (Parts1 and 2), 2011, of the PNSIS (Proceedings of the Nova Scotian Institute of Science) was successfully completed over the past calendar year.

Part One was a Special Issue or book on "The Birds of Brier Island" (BBI), written by Drs Eric Mills and Lance Laviolette, and printed in a new format with a spectacular cover and larger layout. This book is an essential guide for visitors to Brier Island interested in viewing the wide diversity of birds on and around the island. The Institute printed 1000 copies of the BBI and is actively marketing it throughout the Province. Members are encouraged to help in this endeavour.

The regular issue, PNSIS 46(2), was published in early 2012 in a new format - colored cover with picture, and new typeface throughout the journal. This depicts the new look that the Editors are giving the Proceedings. We hope members are pleased with it. We especially thank Gail LeBlanc (Dalhousie University, Layout and Copy) for her skilled and dedicated work on the Proceedings and its new design.

Throughout 2011, the Editorial Board across the Province worked hard to attract papers and then move them through the review process. The new reviewing process is working well and the Journal is starting to attract more papers and ones on a wide range of scientific topics. We have an excellent and enthusiastic team running the Proceedings. The Board is thanked for its work. We also thank Sarah Stevenson, Dalhousie University, stepping down as Production Editor to the NSIS.

So far in 2012, five contributed papers and four student papers are in the review process for PNSIS Volume 47(1) 2012. An editorial is being drafted. A list of prospective papers and editorials is guiding future work on the Proceedings throughout this special Anniversary year and beyond. We are seeking ideas for a Special Issue for Volume 47(2). Each Issue of the Proceedings from now on will have a unique colored cover, and the internal layout facilitating more pleasurable reading. We are making the Proceedings available in both print and electronic formats (on the website, one year after publication). All 
previous volumes will soon be available on our website. Eventually, with the concurrence of members, the Proceedings will only be available as e-copies.

As ever, papers of original science, review papers, commentaries and editorials are requested from all members of the NSIS and from other societies and individuals in the Province and beyond. Supported by the website, the Proceedings are the visible, written voice piece for the NSIS. We hope that members and others keep contributing to it, as it serves science and society in the Maritimes and Atlantic Region with excellence for another 150 years.

Peter G. Wells, Editor PNSIS

(Dalhousie University, Halifax, NS)

David H.S. Richardson, Associate Editor, PNSIS

(Saint Mary's University, Halifax, NS). 


\section{LIBRARIAN'S REPORT 2011/2012}

\section{Prepared for AGM May 8, 2012}

The 2011/2012 year has been very productive and a number of library-related special projects have been completed.

\section{Digitization of the Proceedings of the Nova Scotian Institute of Science}

At the Council meeting of April $4^{\text {th }}, 2011$ a cheque for $\$ 2205.00$ was received to hire a student for 140 hours to work on the digitization of Volume 19 (1934- 1938) to Volume 25 (1958-1962) of the Proceedings of the Nova Scotian Institute of Science. Nicole Radzikowski, a student from the School for Information Management at Dalhousie, was hired and completed the digitization to the end of Volume 25 in May 2011. Then, over the summer, one of the Killam Library intern students, Lora Hamilton, continued work on the digitization project and completed to the end of Volume 34,1984. All of these volumes are now available online through DalSpace and can be viewed at http:// www.library.dal.ca/collections/digitalcollections/nsis

On January 19,2012 , as part of the $150^{\text {th }}$ anniversary celebrations for NSIS, there was a very successful event sponsored jointly by the Dalhousie University Libraries and NSIS to launch the digitized Proceedings.

\section{Institutional Members and Exchange Partners}

There are currently 24 institutional members and 103 NSIS exchange partners. The number of institutional members has remained the same as last year. The number of exchange partners was drastically reduced this year. It was determined that of the 179 exchange partners we had, 75 had not sent any publications in exchange for receiving the Proceedings of NSIS for 2 years or more. A letter was sent to these Institutions stating that due to the high cost of postage and the lack of exchange material we were cancelling our exchange with them. Information was supplied about the availability of institutional memberships and the URL was supplied to access the back issues of the Proceedings online. One institution, Glasgow Natural History Society, cancelled their exchange with us.

Volume 46, parts 1 and 2 of the Proceedings of the Nova Scotian Institute of Science were both published in 2011. The two issues 
were sent to institutional members in one mailing to save on the cost of postage. The mailing to exchange partner institutions is currently being prepared. We are investigating the most reasonable rates for overseas postage.

\section{Sales of the Proceedings of the Nova Scotian Institute of Science}

Over the summer 27 copies of the Flora were sold to two classes, one at Acadia University and one at Dalhousie University. Sales of volumes of the Proceedings during 2011/2012, including the new title Birds of Brier Island, have generated $\$ 3,079.50$ in revenue. (See Appendix A (attached) for details.)

\section{Access Copyright}

The Librarian submitted the required forms to Access Copyright for the 2011 repertoire payment to publishers in June. A cheque in the amount of $\$ 590.43$ was received.

\section{Inventory of NSIS exchange journal collection}

There is a space shortage in the Killam Memorial Library and the new University Librarian at Dalhousie, Donna Bourne-Tyson, has inquired about the collection of exchange volumes stored in the basement of Killam Library. It currently occupies 304 shelves. The NSIS librarian arranged for a SIM student, David Reynolds, to complete a 100-hour practicum work project to assess the uniqueness of the material in this collection in April 2012. He listed the titles in the collection and then proceeded to determine if the journals are available electronically online or if they are held by other Canadian libraries. Recommendations will be brought to Council next year re: the future of this collection.

\section{Change of mailing address:}

The new mailing address reported in last year's Librarian Report has been changed again, and is:

Nova Scotian Institute of Science

c/o Killam Memorial Library

Dalhousie University

6225 University Avenue

PO Box 15000

Halifax, NS Canada B3H 4R2 
Publications continue to be received regularly from our active exchange partners and this material is added on an ongoing basis to the collection. I would like to thank Carol Richardson and the Serials Department staff in the Killam Library who ensure that the NSIS Library operations continue to function smoothly.

I am taking an early retirement from Dalhousie University Libraries effective June 30, 2012. Because of this retirement, I am resigning my position as NSIS Librarian effective at the AGM in May 2012. I became the NSIS Librarian at the AGM in May 1995, and I have enjoyed being the NSIS Librarian for the past 17 years and serving as a member of the NSIS Council. I am very pleased to announce that Michelle Paon, a science librarian at Dalhousie University and a current member of the NSIS Council, has agreed to become the NSIS Librarian, effective immediately.

Respectfully submitted,

Sharon Longard

NSIS Librarian

May 2, 2012 


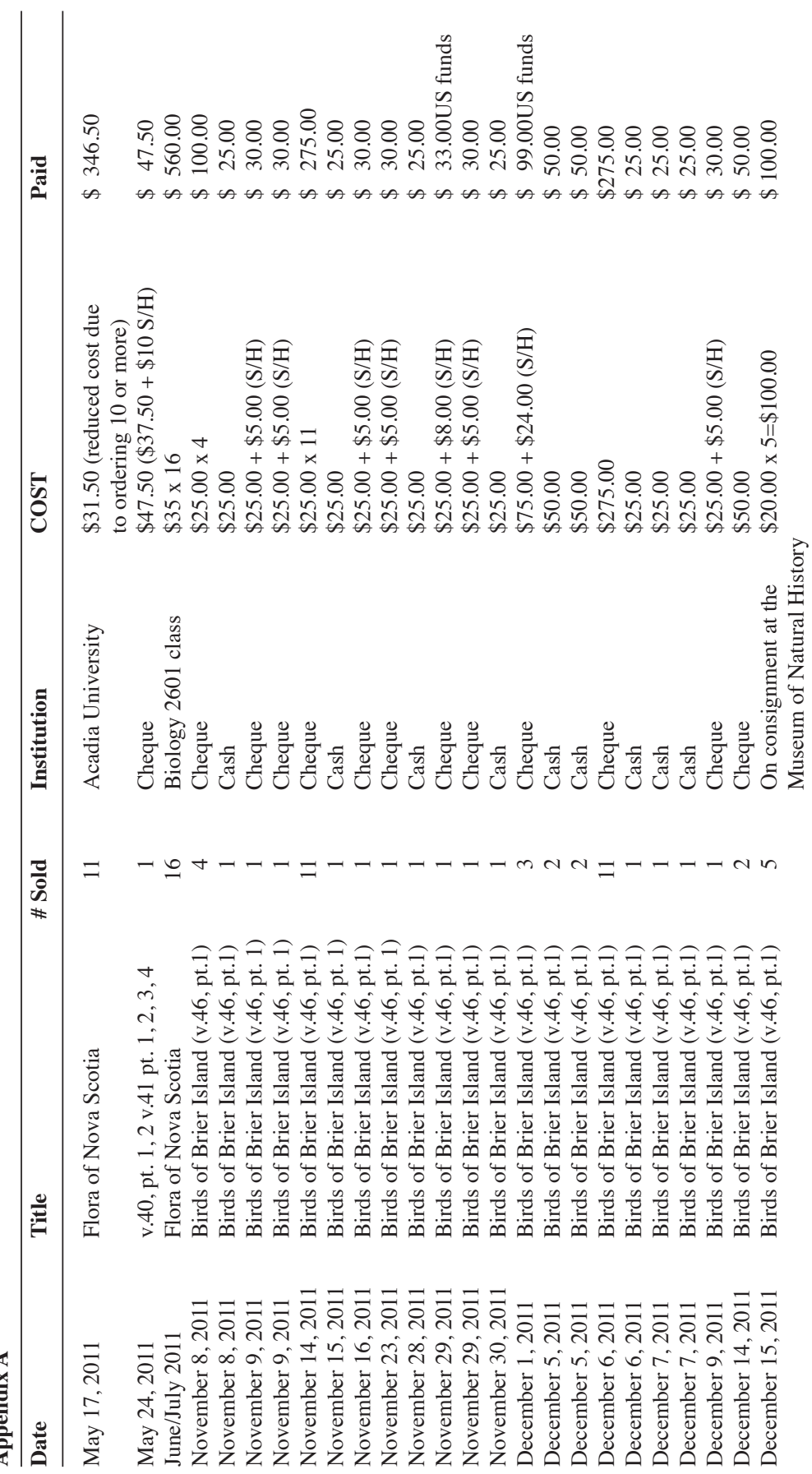


PROCEEDINGS OF THE NOVA SCOTIA INSTITUTE OF SCIENCE 183

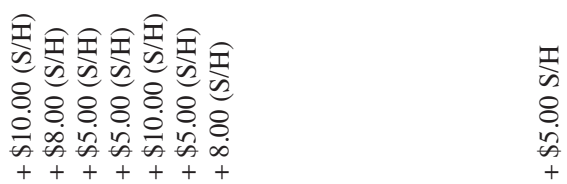

与 \& \& \& \& \& \& \& \& \& \& \& \& \& \& \& \& \& \& \%

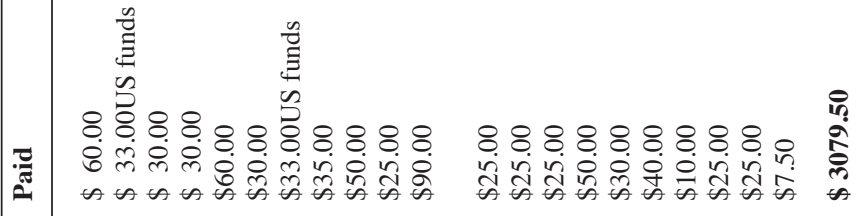

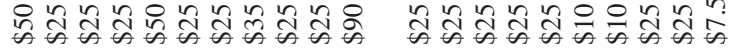

兽

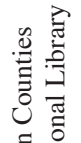

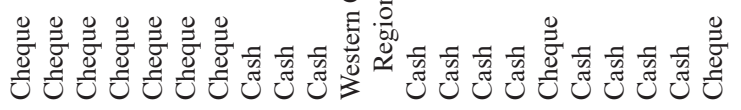

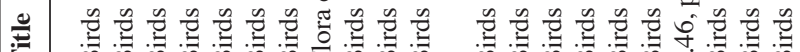

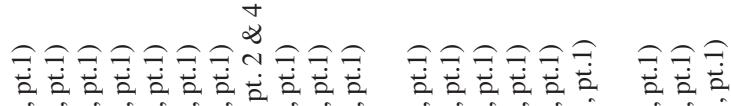

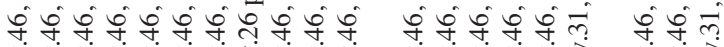

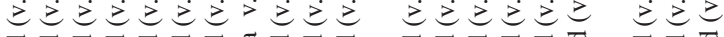

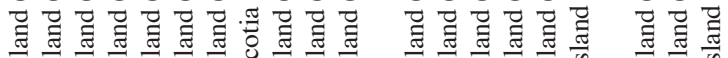

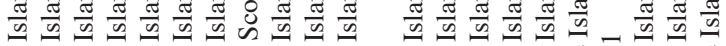
岛 Фض

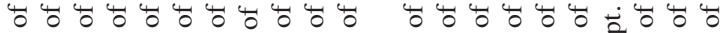

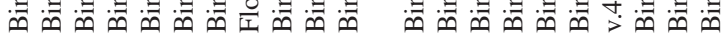

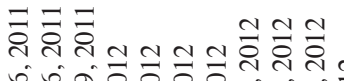
을

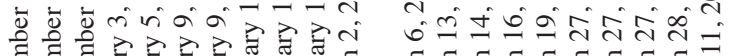
है है 芉

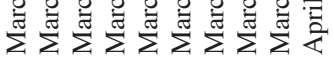




\section{TREASURER'S REPORT NOVA SCOTIAN INSTITUTE OF SCIENCE MARCH 31, 2012}

\section{ASSETS:}

Bank Account

$3,374.70$

Investments

$52,401.46$

TOTAL ASSETS

$55,776.16$

\section{LIABILITIES AND NET WORTH:}

Accounts Payable

Science Fair $\quad 150.00$

NET WORTH

$55,626.16$

TOTAL LIABILITIES AND NET WORTH

$68,742.58$

\section{INVESTMENTS:}

Renaissance High Interest Savings Account

CIBC Investment

Certificate A @ 5.20\% (due Oct. 2012)

$20,000.00$

National Bank of Canada

Certificate A@2.900\% (due May 2013)

$10,300.00$

Montreal Trust Company

Certificate A@3.250\% (dueJuly15 2015)

$10,000.00$

Laurentian Bank

Certificate A@2.700\%( dueJun15,2015)

10.000 .00

TOTAL INVESTMENTS

$52,401.46$ 


\section{REVENUE AND EXPENDITURES FOR 2011-2012}

\section{REVENUE}

Membership Dues

Individuals

$\$ 3,305.00$

Institutions

625.02

AGM (2011)

$1,006.00$

Transfer from Savings

$13,000.00$

Donations/Grant

110.00

Sales/Page charges

Proceedings

$1,795.82$

Other-Flora

941.50

Postage for Proceedings

128.00

Income/Royalties

Investment Income (2011 Calendar Year)

$2,350.84$

Access Copyright Royalty

641.40

Bank Interest

0.62

$\$ 23,904.20$

EXPENDITURES

Advertisement/Promotion

$\$ 881.09$

AGM (2010)

$1,186.86$

Office supplies

19.29

Rent

224.02

Postage

462.40

Donations/Prizes

$2,000.00$

Proceedings Costs

$19,089.44$

Correction

(cheque issued to NSIS in error)

40.00

$\$ 23,903.10$

Net gain: \$1.10 


\section{Finances}

The net worth of the Institute is $\mathbf{\$ 5 5 , 6 2 6 . 1 6}$. For this year, the Institute received $\$ 641.40$ from ACCESS copyright for publication royalties. Expenditures for donations and prizes totalled $\$ 2,000.00$. This included donations of $\$ 150.00$ to each of 10 regional Science Fairs in Nova Scotia, and one writing competition award of $\$ 500.00$ for a graduate student.

\section{Membership}

The Institute has 122 individual members including 8 life members and 3 student members. This year there were 32 new members. Dues from individual members amounted to $\$ 3,305.00$ and from institutional members $\$ 625.02$.

Respectfully submitted to the AGM

May 8, 2012

Elaine D. McCulloch

Treasurer 


\title{
NOMINATIONS TO POSITIONS ON NSIS COUNCIL 2012-2013
}

\author{
President: \\ Michelle Paon \\ Vice-President: \\ Tom Rand* \\ Past President: \\ John Rutherford \\ Secretary: \\ Linda Marks \\ Treasurer: \\ Angelica Silva \\ Editor: \\ Peter Wells \\ Librarian: \\ Michelle Paon \\ Webmaster: \\ Suzuette Soomai \\ Publicity: \\ Regis Dudley

\section{Councillors} \\ Henry (Hank) Bird (Writing Competition Coordinator) \\ Leigh Ann Bishop* (Science Teacher's Rep) \\ Robert Boudreau (Mentorship) \\ Kevin Hewitt* \\ Ron MacKay§ \\ Elaine McCulloch \\ Rick Singer \\ John Young
}

Student Representative

Allison Chua*

\section{Observers}

David Christianson (Nova Scotia Museum)

Vacant (Discovery Centre)

* New members on Council

$\S$ Returning 


\section{REPORT OF THE 150TH ANNIVERSARY COMMITTEE \& BANQUET COMMITTEE}

\section{Annual General Meeting - May 8th, 2012}

During the 2011-2012 season, the NSIS Anniversary Committee met five times in order to plan and undertake anniversary initiatives. Publicity for and marketing of the events was also taken into consideration. In a departure from previous years, a full colour promotional brochure was produced, which included photos of the upcoming lecture speakers as well as information about the lectures and events. Copies of the brochure were supplied to NSIS members and lecture attendees and were distributed to public libraries and large public venues such as the Dalhousie Arts Centre and the New Seaport Farmers' Market.

The NSIS lecture posters were also produced in colour, including a photo of the speaker along with the location, time and lecture information. Print posters were distributed to university campus locations, public libraries, and a number of other high traffic locations. In addition, a PDF copy of each lecture poster was mounted on the NSIS website. Both the brochures and posters received a very favourable response and may have contributed to the high attendance at this year's NSIS public lectures.

Email messages about the monthly lectures were distributed to a wide range of potential audiences, including NSIS members, non-profit organizations involved in science/environmental issues/history, science teachers and science fair coordinators throughout the province, faculty members and graduate students in science, engineering and medicine, and colleagues at the Bedford Institute of Oceanography, among others. In addition, the NSIS anniversary events were made known to relevant provincial ministries, as well as deans and department chairs in science and engineering at universities throughout the province.

The NSIS lectures were held at three venues: six lectures were presented at the auditorium of the Museum of Natural History, two at the Windsor Theatre of the Art Gallery of Nova Scotia, and one at Alumni Hall at the University of King's College. Attendance at the October to April lectures far exceeded that of previous years, with an average of about 75 people per lecture. In fact, there was a full house at several of the lectures, including the lecture on the Shubenacadie Canal presented by Cameron Ells, which attracted over 100 attendees. 
Several months later, Cameron very graciously repeated the lecture, which attracted another 43 attendees. Due to collaborations with the venue organizations, we have been most fortunate in being able to book the venues at very reasonable rates or free of charge.

In addition to the public lectures, several special events were organized during the year:

- $\quad$ NSIS worked in partnership with the Dalhousie University Libraries to officially launch the online historical Proceedings of the Nova Scotian Institute of Science. This event occurred at the Killam Memorial Library on January 19,2012 and was attended by $30-40$ people.

- The April 2012 NSIS public lecture on gold by Dr. Jacob Hanley was held at the Art Gallery of Nova Scotia auditorium. This lecture served as a prelude to an upcoming exhibit on gold that will be mounted by the gallery.

- $\quad$ The NSIS 150th Anniversary Lecture by Dr. Bernie Lightman was held on Monday, May 7th at the University of King's College and was co-sponsored by the History of Science and Technology (HOST) program at the university. The lecture was followed by a reception at which attendees were treated to anniversary cake and refreshments. The co-sponsorship allowed NSIS to use the lecture hall and reception room at no charge. In addition to the in-kind contribution provided by HOST, the Situating Science Atlantic Node was also very supportive of this event, providing assistance with distribution of posters and sharing the lecture announcement via Facebook ${ }^{\circledR}$.

Throughout the coming year, a number of events have been planned to celebrate the NSIS 150th anniversary, some of which will occur in partnership with other organizations. As an example, on October 6th and 7th in Halifax, Symphony Nova Scotia will highlight the NSIS anniversary during two performances of Franz Joseph Haydn's Creation oratorio. It is hoped that these performances will draw together members of both the scientific and artistic communities in a celebration of the natural world. During the pre-concert chats, host and SNS Board of Directors member Adrian Hoffman will moderate a panel discussion on the links between science and music. He has invited NSIS members and interested scientists from throughout the province to participate as 
panelists in these discussions (six panelists will be chosen from among those who have volunteered their names and topics).

This past year, the Anniversary Chair attended a number of the lectures of the Royal Nova Scotia Historical Society, which afforded an opportunity to share information about the NSIS lecture season. A number of the society's members were later observed in attendance at the NSIS lectures. Further discussions with society President Bertrum MacDonald and Vice-President Claire Campbell resulted in plans to explore areas of common interest, especially related to the history of science in Nova Scotia. As a result, in November, NSIS will partner with the Royal Nova Scotia Historical Society to present a joint lecture by Dr. Suzanne Zeller of Wilfrid Laurier University. Dr. Zeller conducts research into the history of science in Canada and recently has begun to turn her attention to the early Proceedings of the NSIS. We look forward to presenting this lecture to our combined memberships and to the public.

Last year, NSIS met with representatives from the Museum of Natural History in order to propose that the museum develop an exhibit to highlight the NSIS anniversary. The idea received a warm reception, and the museum suggested the theme of "scientific collections". It appears that the museum will mount such an exhibit sometime this year.

NSIS is also looking forward to collaborations with the Bedford Institute of Oceanography (BIO) during its upcoming 50th anniversary celebrations. Our colleagues at BIO have been very supportive in terms of promoting NSIS events to BIO researchers and staff, and by distributing lecture posters and brochures.

The NSIS Banquet Committee met four times during the year to plan the May 8th banquet event. In June 2011, a brief survey was sent to NSIS members to determine the number interested in attending a banquet and to gauge potential price sensitivity to the cost of the banquet ticket. The survey indicated that there might be approximately 60 attendees and that a price point of $\$ 50$ was acceptable.

Four potential venues were considered, and in the final analysis, the Lord Nelson Hotel was selected. Due to a very generous in-kind contribution by the hotel, the rental fee was waived for both the reception room (Admiral Room) and the banquet room (Georgian Lounge).

The banquet registration form and an invitation from the NSIS President were sent to members in late February 2012. Members were 
also given the opportunity to purchase "NSIS 150 " commemorative tumblers created by Nova Scotian Crystal. The final tally of banquet registrations was 62 .

A number of the Banquet Committee meetings were held in conjunction with the Anniversary Committee in order to share information and distribute tasks. The banquet event includes a reception, dinner, and the Hall of Fame inductions of Dr. Willard S. Boyle and Dr. Kenneth Mann. In addition, Dr. W. B. (Bev) Scott will be recognized as a long-standing member of the Institute. The families of both Hall of Fame honourees will be in attendance, as will the Honourable David A. Wilson, provincial Minister of Communities, Culture and Heritage, his Executive Assistant Nathaniel Smith, and Ms. Michèle Raymond, Member of the Legislative Assembly for Halifax Atlantic.

The banquet program to be distributed to attendees will include profiles of the honourees, as well as congratulatory messages from NSIS partners such as the Museum of Natural History, the Bedford Institute of Oceanography, the National Research Council, Dalhousie University Libraries, and Situating Science Atlantic Node.

The Chair expresses her sincere thanks to the members of both the NSIS 150th Anniversary Committee and Banquet Committee for their support, their creativity, and their generous commitment of time during the past year. The members of the NSIS Banquet Committee included Linda Marks, Elaine McCulloch, Angelica Silva, Michelle Paon (Chair) and John Rutherford. The members of the NSIS 150th Anniversary Committee will continue their work until the end of the 2012 calendar year. They include: Hank Bird, Bob Cook, Michelle Paon (Chair), John Rutherford, and Peter Wells.

Respectfully submitted by Michelle Paon

May 6, 2012 


\section{AGENDA \\ $151^{\text {ST }}$ Annual General Meeting - 8 May 2012 Admiral Room, Lord Nelson Hotel, Halifax, NS}

1. Minutes of 150th AGM, 2011 meeting. MOVED:

SECONDED:

2. Presidents' Annual Report (John Rutherford):

3. Treasurer's Annual Report (Elaine McCulloch)

4. Editor's Annual Report (Peter Wells)

5. Librarian's Annual Report (Sharon Longard)

6. 150th Anniversary Committee Report (Michelle Paon)

7. Nominating Committee for 2012-2013 Report(David Richardson)

8. Dues Increase

9. Lecture Programme for 2012-2013 (Draft)

10. Other Business

11. Adjournment: Moved: 


\section{MINUTES OF THE $150^{\mathrm{TH}}$ ANNUAL GENERAL MEETING}

2 May, 2011

\section{Dalhousie University Faculty Club}

Council Members present: John Rutherford (Vice-President), Stuart Grossert (Past President), Mary-Jane O'Halloran (Past President), Linda Marks (Secretary), Sharon Longard (Librarian), Peter Wells (Editor), Robert Cook (Writing Contest Coordinator), Ron MacKay (Lecture Committee Coordinator), Michelle Paon (150th Anniversary Committee Coordinator)

Members present: Michael Falk, Laura MacDonald

Regrets (Council Members): David Richardson (President), Elaine McCulloch (Treasurer), Robert Boudreau (Mentorship Coordinator), Henry Bird, Angelica Silva

As the President could not be available, John Rutherford welcomed members and called to order the 150th Annual General Meeting. It was noted that the reports will be briefly summarized as all the reports have been made available to members with email prior to the meeting and that paper copies are also available.

1. Approval of the Minutes of the 149th Annual General Meeting of 3rd May, 2010.

Motion to accept the minutes:

MOVED: Robert Cook

Seconded: Michael Falk

No discussion. All in favour. Carried

\section{Annual Reports}

a) President's Report (David Richardson)

John Rutherford highlighted aspects of the President's Report (attachment \# 1) on behalf of David Richardson as follows: 
- The Institute had a very successful year with a well attended lecture program organized by Ron McKay with the help of Angelica Silva and John Rutherford.

- The Institute also co-sponsored the 7th Annual Sable Island meeting which was held at Saint Mary's University.

- A successful Writing Contest awarded two prizes and was organized by Robert Cook.

- Two issues of the Institute's journal the Proceedings of the Nova Scotian Institute of Science were published, thanks to the Editor, Peter Wells, and the Editorial Board, with financial assistance (in the form of a grant) provided by the Nova Scotia Department of Tourism and Heritage.

- The Institute provided financial support to ten regional science fairs.

- Dalhousie University, which houses the NSIS library, has digitized issues of the Proceedings of the Nova Scotian Institute of Science for the years $1862-1934$.

- The Institute will celebrate its 150th Anniversary in 2012 and a committee, chaired by Michelle Paon is working on events to highlight and celebrate the event.

The Institute is indebted to the Museum of Natural History for its support and to David Christianson, the Museum's Manager of Collections for his assistance.

The President noted in his report that "The Institute has a long and proud history and will celebrate 150 years of promoting science to Nova Scotians in 2012. Few other Canadian organizations can boast this track record."

The President thaned all members of Council for their diligence and hard work during the past year.

Motion to accept the President's Report:

MOVED: Robert Cook

Seconded: Michael Falk

No discussion. All in favour. Carried 


\section{b) Editor's Report (Peter Wells/Associate Editor,D.Richardson)} Peter Wells presented the Editor's report (attachment \# 2) and reported that Proceedings Vol. 45 (Parts 1 and 2) were successfully completed and that Vol. 46 (parts 1 and 2) are underway. The Editor reported that the Editorial Board has been strengthened; guidelines for manuscript flow have been developed; and that journal layout and production is supported by two Dalhousie staff members, Sarah Stevenson and Gail LeBlanc.

The Editor stressed that Institute members are welcomed to submit papers and editorials and that the Journal, supported by the Institute's Website, is an important voice for the Institute and science in Nova Scotia.

\section{Motion to accept the Editor's Report: \\ MOVED: Ron McKay \\ Seconded: Robert Cook \\ No discussion. All in favour. Carried}

\section{c) Treasurer's Report}

John Rutherford presented the Treasurer's report (attachment \# 3) which stated that the Institute has a "net worth" of $\$ 68742.58$. Revenue included a grant from the Nova Scotia Government, investment income; royalties from ACCESS copyright; the sale of the Proceedings; and membership (individual and institutional) dues. Expenditures included the printing and mailing of the Proceedings and donations; promotional materials; and prizes to the Writing Contest and province-wide Science Fairs.

The Institute currently has 106 members.

Michael Fak agreed to audit the Report. Thanks were given to the auditor.

Motion to accept the Treasurer's Report:

MOVED: Peter Wells

Seconded: Ron McKay

No discussion. All in favour. Carried

\section{d) Librarian's Report}

Sharon Longard reported highlights of her report (attachment \# 4). NSIS has 179 exchange partners and 24 institutional members. 
Sales of past Proceedings generated $\$ 930.50$ in revenue. A project to digitize the Institute's Journal is continuing. During the summer 2010, Vols. 13 to 18 (1910-1934) of the Proceedings have been digitized through an initiative of the Dalhousie University Libraries and can be viewed at http://www.library.dal.ca/collections/digitalcollections/nsis. Council approved a request, from the Librarian, for funding for the digitization of Vols. 19 to 25 (1934-1962) of the Proceedings. This project will complete the first 100 years of the Journal.

\section{Motion to accept the Editor's Report: \\ MOVED: Sharon Longard \\ Seconded: Michael Falk \\ No discussion. All in favour. Carried}

S. Longard thanked Carol Richardson and the Serials Department staff in the Killam Library at Dalhousie University for ensuring that the NSIS Library continues to function smoothly.

\section{NSIS Website}

Stuart Grossert reported that a proposal to redesign the Institute's website was submitted to Council in April. The present website, while well laid out, is difficult to modify due to its complexity. It has been proposed that that be contracted to work with the incoming Webmaster to produce a simpler website, which would be easier to modify. Past Webmaster, John Cordes has volunteered to assist and meetings are planned prior to October. Stuart Grossert wished to stress the importance of the website to the Institute.

\section{Anniversary Committee (Michelle Paon)}

Chair, Michelle Paon presented a report (attachment \#5) on behalf of the Committee (John Rutherford, Hank Bird, Robert Cook, Peter Wells and Michelle Paon). Special public lectures are planned with one to be held at the Art Gallery of NS and a May Anniversary Lecture by Dr. Bernie Lightman from York University. The Committee is collaborating with Dalhousie University's School for Resource and Environmental Studies to host the Killam Memorial Lectures and along with the Institute`s Librarian, Sharon Longard, is partnering with Dalhousie University Libraries to officially launch the online Proceedings in January 2012. 
A Banquet Committee (Michelle Paon, Elaine McCulloch, John Rutherford and Linda Marks) has been established to plan the Anniversary Banquet which will include a reception, dinner and a Hall of Fame presentation.

\section{Other}

In addition, the Committee is working towards collaborative initiatives with the Bedford Institute of Oceanography, which will celebrate its 50th anniversary in 2012. The Committee is also hoping that the Institute will be selected by Canada Post for a commemorative stamp.

Ron MacKay felt that the Institute should offer to cover some of the costs for the Killam Lecture Series so that we may have some influence over the lectures. John Rutherford emphasized that we do retain influence as members of the committee and can participate in the costs for refreshments. Michelle Paon may look at ideas to involve sponsors for the event.

Sharon Longard suggested that the brochure for 2011-2012 give advance notice of the banquet and Robert Cook suggested that the Premier of the Province be invited to the event.

Stuart Grossert congratulated the committee for its work and hoped that word will get out concerning these significant activities in 2012.

\section{Report of the Nominating Committee and Election of Council} for 2011 - 2012 (Mary-Jane O'Halloran)

Mary-Jane O'Halloran presented the nominations (attachment \#6) for the 2011-2012 Council on behalf of the Committee (Stuart Grossert, David Richardson, John Rutherford and Mary-Jane O'Halloran).

There were three calls for additional nominations from the floor. As there was "no contest" to the proposed slate of officers it was declared that the nominations be elected by acclimation.

New members to Council are Suzuette Soomai (Webmaster), Richard Singer and John Young.

\section{Other Business}

Stuart Grossert suggested that in future the minutes from the April Council meeting be approved by the outgoing Council and not left 
until the following October's first meeting with a new Council. The outgoing Council could meet just prior to the AGM to discuss and approve the minutes.

Stuart Grossert expressed thanks to David Richardson for his work as President.

\section{Adjournment}

It was moved by Peter Wells that the meeting be adjourned at 9:55 PM.

Respectfully submitted, Linda Marks

Secretary 